\title{
A New Depsipeptide Antibiotic, Citropeptin
}

\author{
Yoichi Hayakawa, Masaya NaKagawa, * Yoichiro Toda* \\ and Haruo SETO \\ Institute of Applied Microbiology, University of Tokyo, \\ Bunkyo-ku, Tokyo 113, Japan \\ * Pharmaceutical Laboratory, Kirin Brewery Co., Ltd., \\ Miyahara, Takasaki, Gunma 370-12, Japan \\ Received October 24, 1989
}

\begin{abstract}
An actinomycete identified as Streptomyces flavidovirens was found to produce a new cyclic hexadepsipeptide antibiotic, designated citropeptin. Citropeptin showed antitumor activity against P388 murine leukemia.
\end{abstract}

In the course of our screening program for new antitumor antibiotics, culture K3619, identified as a strain of Streptomyces flavidovirens, was isolated. This organism was found to produce an antibiotic, designated citropeptin, with potent cytotoxicity. The structure of this antibiotic was elucidated by NMR spectral analysis to be a cyclic hexadepsipeptide closely related to azinothricin ${ }^{11}$ and A83586C. ${ }^{2)}$ This paper describes the taxonomy of the producing organism and the fermen- tation, isolation, physicochemical properties and biological activity of citropeptin.

\section{Taxonomy}

Culture K3619 was isolated from a soil sample collected in Brazil. Characterization of the strain was done mainly by the method described by Shirling and Gottlieb. ${ }^{3)}$

The cultural characteristics of strain K3619 on various media are presented in Table I. The culture grew poorly on defined media such as

Table I. Cur tural Characteristics of Strain K3619

\begin{tabular}{|c|c|c|c|}
\hline Medium & $\begin{array}{l}\text { Vegetative } \\
\text { mycelium }\end{array}$ & $\begin{array}{l}\text { Aerial } \\
\text { mycelium }\end{array}$ & $\begin{array}{l}\text { Soluble } \\
\text { pigments }\end{array}$ \\
\hline $\begin{array}{l}\text { Sucrose-nitrate agar } \\
\text { (Waksman No. 1) }\end{array}$ & $\begin{array}{l}\text { Poor, } \\
\text { colorless }\end{array}$ & $\begin{array}{l}\text { Poor, powdery, } \\
\text { yellowish white }\end{array}$ & None \\
\hline $\begin{array}{l}\text { Glucose-asparagine } \\
\text { agar (Waksman No. 2) }\end{array}$ & $\begin{array}{l}\text { Poor, pale } \\
\text { yellowish brown }\end{array}$ & $\begin{array}{l}\text { Very poor, } \\
\text { powdery, white }\end{array}$ & None \\
\hline $\begin{array}{l}\text { Glycerol-asparagine } \\
\text { agar (ISP No. 5) }\end{array}$ & $\begin{array}{l}\text { Poor, pale } \\
\text { yellowish brown }\end{array}$ & None & None \\
\hline $\begin{array}{l}\text { Inorganic salts- } \\
\text { starch agar } \\
\text { (ISP No. 4) }\end{array}$ & $\begin{array}{l}\text { Moderate, } \\
\text { pale yellowish } \\
\text { brown }\end{array}$ & $\begin{array}{l}\text { Abundant, powdery, } \\
\text { pale yellow to } \\
\text { light olive gray }\end{array}$ & None \\
\hline $\begin{array}{l}\text { Tyrosine agar } \\
\text { (ISP No. } 7 \text { ) }\end{array}$ & $\begin{array}{l}\text { Poor, pale } \\
\text { yellowish brown }\end{array}$ & None & None \\
\hline Nutrient agar & $\begin{array}{l}\text { Moderate, } \\
\text { yellow }\end{array}$ & $\begin{array}{l}\text { Very poor, } \\
\text { powdery, white }\end{array}$ & None \\
\hline $\begin{array}{l}\text { Yeast extract- } \\
\text { malt extract agar } \\
\text { (ISP No. 2) }\end{array}$ & $\begin{array}{l}\text { Moderate, } \\
\text { pale yellowish } \\
\text { brown }\end{array}$ & $\begin{array}{l}\text { Moderate, } \\
\text { powdery, } \\
\text { pale yellow }\end{array}$ & None \\
\hline $\begin{array}{l}\text { Oatmeal agar } \\
\text { (ISP No. 3) }\end{array}$ & $\begin{array}{l}\text { Moderate, pale } \\
\text { yellowish brown }\end{array}$ & $\begin{array}{l}\text { Poor, powdery, } \\
\text { yellowish white }\end{array}$ & None \\
\hline
\end{tabular}


Waksman media No. 1 and No. 2, and moderately on inorganic salts-starch agar, nutrient agar and yeast extract-malt extract agar. The aerial mass color was white or in the

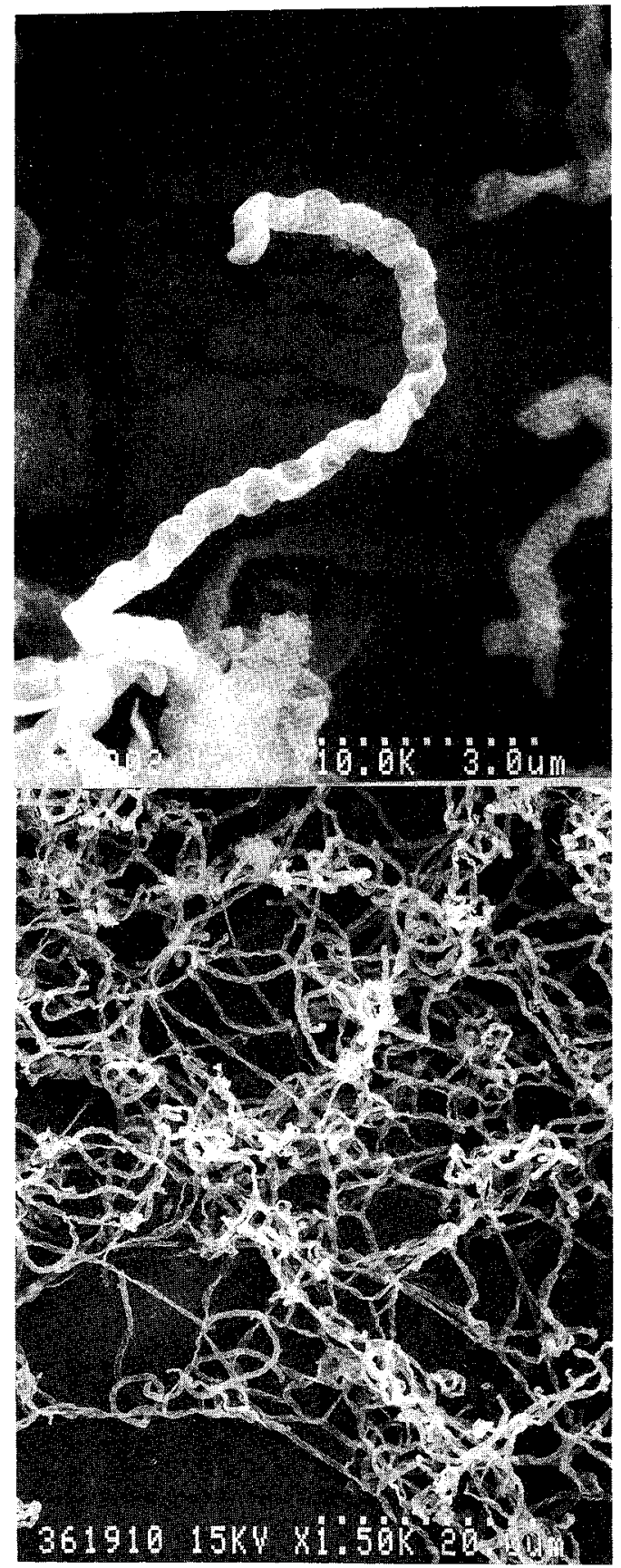

Fig. 1. Electron Micrographs of Spore Chains of Strain K3619 on Inorganic Salts-Starch Agar, 14 Days (Top: $\times 1,500$, Bottom: $\times 10,000$ ).
Yellow color series (yellowish white to pale yellow or light olive gray). The reverse color was pale yellowish brown to yellow. Melanoid pigments or other soluble pigments were not produced.

The aerial mycelium branched monopodially. The spore chains, with $10-50$ spores per chain, were very flexuous and occasionally formed imperfect or open spirals (Retinaculiaperti). The spores were oval to cylindrical in shape $(0.6-0.8 \mu \mathrm{m} \times 0.8-1.0 \mu \mathrm{m})$ with a smooth surface (Fig. 1).

The whole cell hydrolysate contained LLdiaminopimelic acid (DAP), but not mesoDAP. These were analyzed as their GITC derivatives by HPLC on a ODS column. ${ }^{4}$

The physiological properties were as follows. Strain K 3619 was able to grow at $20^{\circ} \mathrm{C}$ to $30^{\circ} \mathrm{C}$. The culture utilized D-xylose, Dglucose, inositol, D-mannose, melibiose and trehalose, but not L-arabinose, D-fructose, sucrose, L-rhamnose, raffinose or D-ribose. The strain weakly peptonized milk, but did not either hydrolyze starch, liquefy gelatin, coagulate milk or reduce nitrate. Melanoid pigments were not produced on tyrosine agar, peptone-yeast-iron agar or tryptone-yeast-iron agar.

The above morphological and chemical characteristics assign this strain to the genus Streptomyces. Comparative study of the characteristics of similar strains in the literature indicates that strain K3619 is most similar to Streptomyces flavidovirens. Strain K3619 and $S$. flavidovirens are agree well on their spore chain morphology, aerial mass color, reverse color and pigment production, but are different in their utilization of L-arabinose. The reports for $S$. flavidovirens vary on the utilization of several carbon sources, ${ }^{5)}$ and it was very difficult to identify the carbon utilization of strain K 3619 because of its poor growth on Pridham-Gottlieb medium. Therefore, strain K3619 was identified as Streptomyces flavidovirens. ${ }^{5,6\}}$

\section{Fermentation and isolation}

Strain K3619 was cultured at $27^{\circ} \mathrm{C}$ for 3 
days on a rotary shaker in 500-ml Erlenmeyer flasks containing $100 \mathrm{ml}$ of a medium consisting of glucose, $0.4 \%$; malt extract, $1 \%$; and yeast extract $0.4 \%(\mathrm{pH} 7.2)$. The above seed culture $(300 \mathrm{ml})$ was transferred into a $50-1$ jar fermentor containing $25 \mathrm{l}$ of a medium consisting of glucose, $2.5 \%$; soybean meal, $1.5 \%$; dry yeast, $0.2 \%$, and calcium carbonate $0.4 \%(\mathrm{pH}$ 7.0). The fermentation was carried out at $27^{\circ} \mathrm{C}$ for 5 days with aeration $(10 \mathrm{l} / \mathrm{min})$ and agitation $(200 \mathrm{rpm})$.

The whole broth (50 1) was filtered through Celite and the mycelial cake was extracted with 251 of acetone. After evaporation in vacuo, the extract was partitioned between $10 \mathrm{l}$ each of ethyl acetate and water. The organic layer was concentrated to dryness, and then chromatographed on a silica gel column. Development of the column $(5 \times 60 \mathrm{~cm})$ with chloroformethanol $(50: 1)$ gave an active fraction, which was evaporated to dryness and put on a second silica gel column $(4 \times 50 \mathrm{~cm})$. The crude active material eluted with chloroform-ethyl acetate
(2:1) was concentrated in vacuo and then chromatographed on a Sephadex LH-20 column $(2.5 \times 50 \mathrm{~cm})$ with methanol. The active eluate was evaporated to dryness and crystallized from ethanol to yield $270 \mathrm{mg}$ of colorless needles of citropeptin.

\section{Physicochemical properties}

mp 109-111 C. Anal. Found: C, 58.11; H, $7.88 ; \mathrm{N}, 10.77 ; \mathrm{O}, 23.00 \%$. Calcd. for $\mathrm{C}_{50} \mathrm{H}_{82} \mathrm{~N}_{8} \mathrm{O}_{15}: \mathrm{C}, 58.01 ; \mathrm{H}, 7.98 ; \mathrm{N}, 10.82 ; \mathrm{O}$, $23.18 \%$. FD-MS $m / z 1035(\mathrm{M}+\mathrm{H}), 1057$ $(\mathrm{M}+\mathrm{Na}) . \mathrm{IR}\left(\mathrm{CHCl}_{3}\right) \mathrm{cm}^{-1} 3400,2950,1730$, $1665,1640,1495,1460,1390,1315,1280,1120$, 1005. UV $\lambda_{\text {max }}(\mathrm{MeOH}) \mathrm{nm}(\varepsilon) 230(\mathrm{sh} \mathrm{14,000).}$ $[\alpha]_{\mathrm{D}}^{25}+113^{\circ}\left(c 0.5, \mathrm{CHCl}_{3}\right)$. The $500 \mathrm{MHz}{ }^{1} \mathrm{H}$ NMR spectrum as shown in Fig. 2 was obtained in $\mathrm{CDCl}_{3}$ solution at $27^{\circ} \mathrm{C}$ on a $\mathrm{JEOL}$ GX-500 spectrometer.

The structure of citropeptin as shown in Fig. 3 , except for the stereochemistry, was elucidated by NMR spectral analysis including a variety of two-dimensional techniques. The

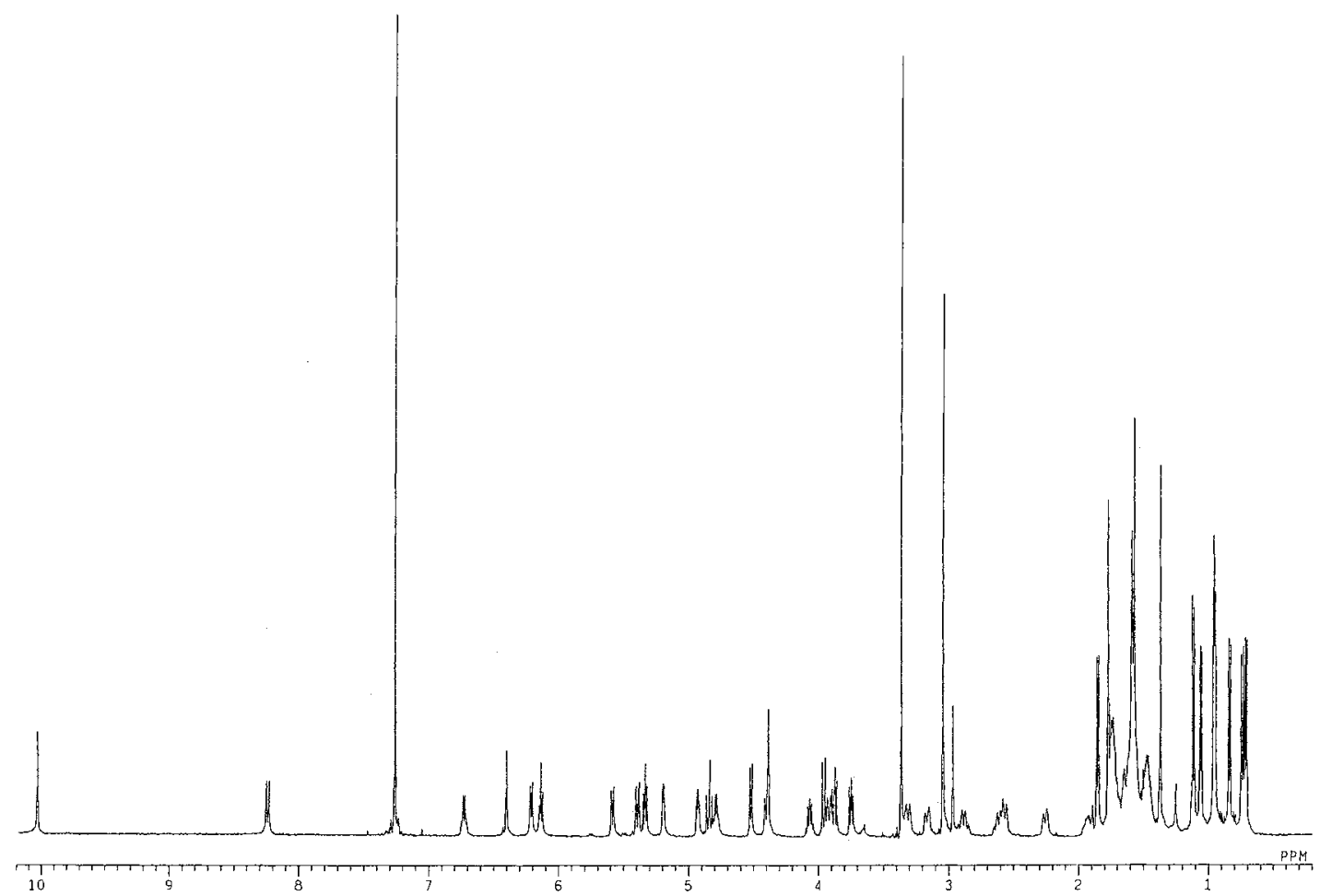

Fig. 2. ${ }^{1} \mathrm{H}$ NMR Spectrum of Citropeptin $\left(500 \mathrm{MHz}, \mathrm{CDCl}_{3}\right)$. 


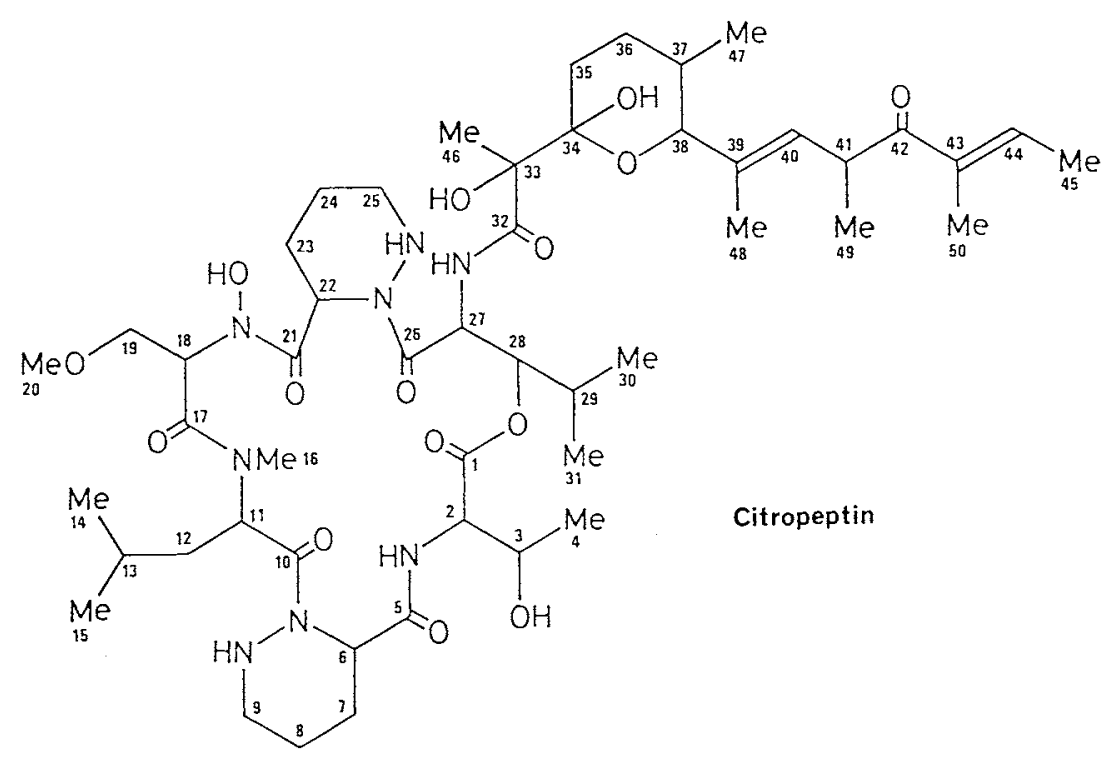

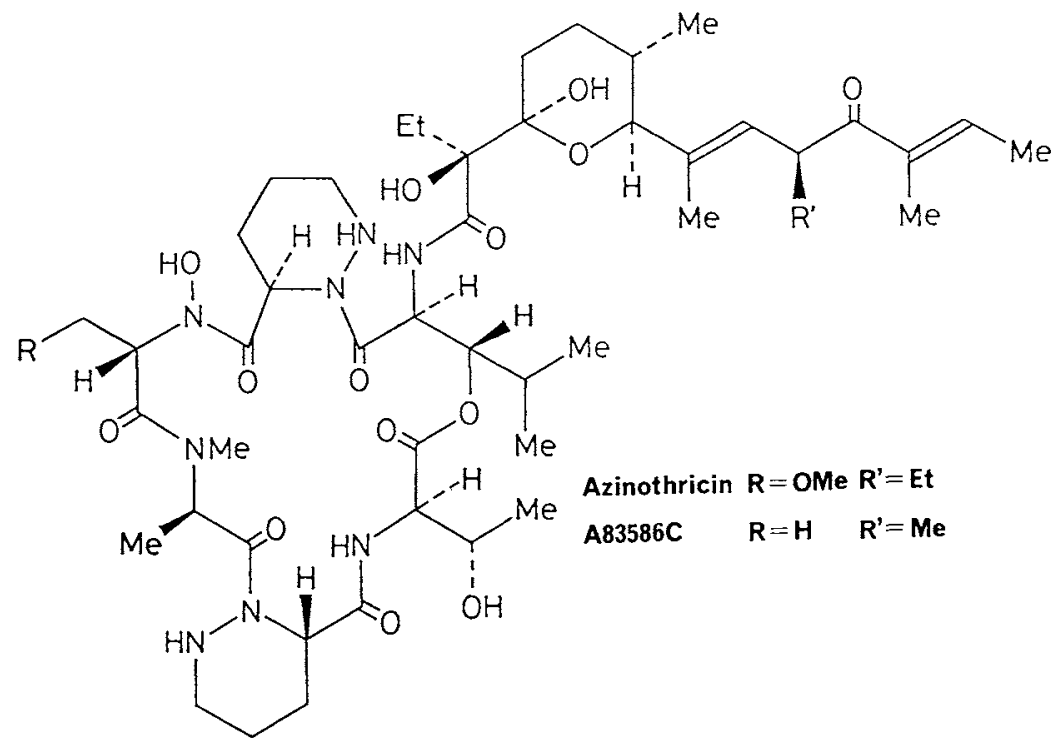

Fig. 3. Structures of Citropeptin, Azinothricin and A83586C.

structural study will be reported elsewhere.

\section{Biological activity}

Citropeptin was. very cytotoxic with $\mathrm{IC}_{50} \mathrm{~s}$ of $0.02 \mu \mathrm{g} / \mathrm{ml}$ and $0.1 \mu \mathrm{g} / \mathrm{ml}$ against murine P388 leukemia cells and B16 melanoma cells, respectively, which were incubated at $5 \times 10^{4}$ cells $/ \mathrm{ml}$ with various concentrations of citrop- eptin in RPMI1640 medium supplemented with $10 \%$ fetal calf serum for 2 days.

$\mathrm{CDF}_{1}$ mice were inoculated intraperitoneally with $10^{6}$ P388 leukemia cells and treated intraperitoneally with cirtropeptin on days 1 and 5. Citropeptin prolonged the survival periods of mice bearing P388 (T/C 123\%) at doses of $2 \mathrm{mg} / \mathrm{kg} / \mathrm{day}$, but caused toxic 
death at $4 \mathrm{mg} / \mathrm{kg} / \mathrm{day}$.

\section{References}

1) H. Maehr, C. Liu, N. J. Palleroni, J. Smallheer, L. Todaro, T. H. Williams and J. F. Blount, J. Antibiot., 39, 17 (1986).

2) T. A. Smitka, J. B. Deeter, A. H. Hunt, F. P. Mertz, R. M. Ellis, L. B. Boeck and R. C. Yao, J. Antibiot.,
41, $726(1988)$.

3) E. B. Shirling and D. Gottlieb, Int. J. Syst. Bacteriol., 16, 313 (1966).

4) T. Yamaguchi, J. Bacteriol., 89, 444 (1965).

5) E. B. Shirling and D. Gottlieb, Int. J. Syst. Bacteriol., 19, 391 (1969).

6) R. Locci, "Bergey's Manual of Systematic Bacteriology," Vol. 4, ed. by S. T. Williams, Williams \& Wilkins Co., Baltimore, M.D., 1989. 